\title{
Pengaruh Current Ratio (CR) dan Debt To Asset Ratio (DAR) Terhadap Return On Asset (ROA) Pada Pt. Indocement Tunggal Prakarsa Tbk Periode 2008-2017
}

\author{
Endang Puji Astutik ${ }^{1)}$ \& Ammelia Novita Anggraeny)
}

${ }^{1,2)}$ dosen Universitas Pamulang, email : dosen01682@unpam.ac.id \& ammelianovita@gmail.com

\section{ARTICLES \\ INFORMATION}

ABSTRACT

\section{JURNAL SEKURITAS (Saham, Ekonomi, \\ Keuangandan Investasi) \\ Vol.3, No.1, September 2019 \\ Halaman : $97-111$ \\ (9) LPPM \& Prodi Manajemen \\ UNVERSITAS PAMULANG \\ ISSN (online) : 2581-2777 ISSN (print) : 2581-2696}

\section{Keyword :}

Current Ratio, Debt To Asset Ratio dan Return On Asset

\section{JEL Classification : \\ C31, G10, G29, N65}

\section{Contact Author: \\ PRODI MANAJEMEN UNPAM \\ JL.Surya Kencana No.1 Pamulang \\ Tangerang Selatan-Banten \\ Teip. (021) 7412566 , Fax (021) 7412491 Email: \\ jumalfinance.unpam@gmail.com}

sekuritas@unpam.ac.id
Penelitian ini bertujuan untuk mengetahui pengaruh antara Current Ratio (CR) dan Debt To Asset Ratio (DAR) terhadap Return On Asset (ROA) pada PT. Indocement Tunggal Prakarsa, Tbk.

Metode penelitian yang digunakan dalam penelitian ini adalah metode deskriptif dengan menganalisis laporan keuangan dengan menggunakan data kuantitatif dan teknik data yang digunakan adalah data sekunder. Penelitian ini menggunakan data laporan keuangan tahun 2008 sampai dengan tahun 2017 pada PT. Indocement Tunggal Prakarsa, Tbk. yang diperoleh dari website www.indocement.co.id. Metode analisis data statistik yang digunakan adalah regresi linear berganda dan dilakukan uji asumsi klasik terlebih dahulu. Pengolahan data statistic menggunakan software SPSS 20 for windows.

Hasil penelitian ini menunjukkan bahwa penelitian ini memenuhi uji asumsi klasik. Dari hasil analisis linear berganda, didapat persamaan $Y=-25,588+0,040 X_{1}+1,491 X_{2}+e$. Besarnya koefisien determinasi adalah sebesar 0,585 . Hal ini menunjukkan bahwa Current Ratio dan Debt To Asset Ratio memberikan pengaruh terhadap Return On Asset sebesar $58,5 \%$ sedangkan sisanya $41,5 \%$ dipengaruhi oleh variabel lain. Secara uji parsial (uji t) variabel Current Ratio berpengaruh signifikan terhadap Return On Asset berdasarkan hasil thitung $(3,139)>t_{\text {tabel }}(2,306)$, dengan nilai signifikansi $0,016<0,05$, maka Ho ditolak dan Ha diterima. Sedangkan Debt To Asset Ratio berpengaruh signifikan terhadap Return On Asset berdasarkan hasil $t_{\text {hitung }}(2,626)>t_{\text {tabel }}(2,306)$, dengan nilai signifikansi $0,034<0,05$, maka Ho ditolak dan Ha diterima. Secara uji simultan (uji f) diperoleh hasil $F_{\text {hitung }}(4,926)>F_{\text {tabel }}$ $(4,74)$ dengan nilai signifikansi $0,046<0,05$, sehingga $\mathrm{Ha}$ diterima dan Ho ditolak. Maka dapat disimpulkan bahwa secara simultan Current Ratio dan Debt to Asset Ratio berpengaruh signifikan terhadap Return On Asset. 


\section{A. PENDAHULUAN}

\section{Latar Belakang}

Perkembangan dunia usaha pada era globalisasi saat ini dapat dikatakan sangat cepat, hal ini membuat persaingan antar perusahaan pun semakin meningkat. Setiap perusahaan dituntut untuk dapat bersaing dengan perusahaan lain agar tetap bertahan hidup. Selain itu keadaan ekonomi yang tidak stabil dan merosotnya nilai tukar rupiah terhadap dollar memberikan pengaruh yang cukup besar terhadap perusahaan dalam menentukan harga dan produk. Dikhawatirkan jika menaikkan harga produk, daya beli masyarakat akan produk tersebut berkurang sehingga kemampuan perusahaan harus memadai dalam menghadapi persaingan dengan kompetitor sejenis agar perusahaan dapat mencapai laba semaksimal mungkin. Maka untuk menghadapi persaingan tersebut, perusahaan atau pimpinan perusahaan harus memiliki strategi yang baik terutama dalam efesiensi dan efektivitas dalam mengelola sumber dana yang ada di perusahaan.

Setiap perusahaan dituntut untuk selalu meningkatkan kinerjanya termasuk kinerja keuangannya agar dapat bersaing dengan perusahaan lain, sehingga perusahaan akan dapat menjamin kelangsungan hidupnya. Salah satu untuk melihat kinerja perusahaan adalah dari laporan keuangan yang dibuat perusahaan pada setiap tahunnya. Laporan keuangan digunakan untuk menentukan atau menilai posisi keuangan perusahaan, dimana dengan menganalisa laporan keuangan tersebut pihak-pihak yang berkepentingan dapat menggunakannya sebagai alat pengambilan keputusan. Dengan menganalisa laporan keuangan akan diperoleh banyak informasi yang dikandung dalam laporan keuangan.

Return On Asset (ROA) merupakan salah satu rasio profitabilitas yang digunakan untuk mengukur efektivitas perusahaan di dalam menghasilkan keuntungan dengan memanfaatkan total aktiva yang dimilikinya. ROA merupakan rasio antara laba sesudah pajak terhadap total aset. Menurut Mamduh (2016:81), ROA merupakan rasio keuangan perusahaan yang berhubungan dengan profitabilitas mengukur kemampuan perusahaan menghasilkan keuntungan atau laba pada tingkat pendapatan, aset dan modal saham tertentu. Dengan mengetahui ROA, kita dapat menilai apakah perusahaan telah efisien dalam menggunakan akivanya dalam kegiatan operasi untuk menghasilkan keuntungan. Semakin tinggi nilai ROA maka semakin baik kinerja keuangan perusahaan tersebut. ROA yang negatif disebabkan laba perusahaan dalam kondisi negatif pula atau rugi, hal ini menunjukkan kemampuan dari modal yang diinvestasikan secara keseluruhan belum mampu untuk menghasilkan laba.

Debt to Asset Ratio (DAR) merupakan rasio utang yang digunakan untuk mengukur perbandingan antara total utang dengan total aktiva. Dengan kata lain, seberapa besar aktiva perusahaan dibiayai oleh utang atau seberapa besar utang perusahaan berpengaruh terhadap pengelolaan aktiva (Kasmir, 2016:156). Nilai rasio yang tinggi menunjukkan peningkatan dari resiko kreditor berupa ketidakmampuan perusahaan dalam membayar semua kewajibannya. Dari pihak pemegang saham, rasio yang tinggi akan mengakibatkan pembayaran bunga yang tinggi pada akhirnya akan mengurangi pembayaran dividen.

Menurut Kasmir (2016:134) Rasio lancar atau Current Ratio (CR) merupakan rasio untuk mengukur kemampuan perusahaan dalam membayar kewajiban jangka pendek atau utang yang segera jatuh tempo pada saat ditagih secara keseluruhan. Apabila rasio lancar rendah, dapat dikatakan bahwa perusahaan kurang modal untuk membayar utang. Namun, apabila hasil pengukuran rasio tinggi belum tentu 
kondisi perusahaan sedang baik. Hal ini dapat saja terjadi karena kas tidak digunakan sebaik mungkin.

Berdasarkan uraian di atas, maka penulis tertarik untuk melakukan penelitian untuk mengetahui seberapa besar pengaruh Current Ratio (CR) dan Debt to Asset Ratio (DAR) terhadap Return On Asset (ROA) dengan judul "Pengaruh Current Ratio dan Debt to Asset Ratio terhadap Return On Asset pada PT. Indocement Tunggal Prakarsa Tbk periode 2008 - 2017”.

\section{Perumusan Masalah}

1) Bagaimana pengaruh Current Ratio (CR) terhadap Return On Asset (ROA) di PT. Indocement Tunggal Prakarsa Tbk?

2) Bagaimana pengaruh Debt to Asset Ratio (DAR) terhadap Return On Asset (ROA) di PT. Indocement Tunggal Prakarsa Tbk ?

3) Bagaimana pengaruh Current Ratio (CR) dan Debt to Asset Ratio (DAR) secara bersama-sama terhadap Return On Asset (ROA) di PT. Indocement Tunggal Prakarsa Tbk?

\section{B. KAJIAN LITERATUR}

\section{Laporan Keuangan}

Menurut Ikatan Akuntan Indonesia dalam PSAK No.1 (2017) Laporan keuangan adalah suatu penyajian terstruktur dari posisi keuangan dan kinerja keuangan suatu entitas. Laporan keuangan merupakan bagian dari proses pelaporan keuangan. Laporan keuangan yang lengkap biasanya meliputi neraca, laporan labarugi, laporan perubahan posisi keuangan (yang dapat disajikan dalam berbagai cara misalnya, sebagai laporan arus kas, atau laporan arus dana), catatan dan laporan lain serta materi penjelasan yang merupakan bagian integral dari laporan keuangan.

Menurut Kasmir (2016:7) laporan keuangan merupakan laporan yang menunjukkan kondisi keuangan perusahaan pada saat ini atau dalam suatu periode tertentu.

\section{Current Ratio}

Menurut Sofyan Syafri Harahap (2015:301) current ratio merupakan rasio yang menunjukkan sejauh mana aset lancar menutupi kewajiban-kewajiban lancar. Semakin besar perbandingan aset lancar dengan utang lancar semakin tinggi kemampuan perusahaan menutupi kewajiban jangka pendeknya.

Adapun rasio lancar (current ratio) dapat dirumuskan sebagai berikut:

$$
\text { Current Ratio }=\frac{\text { Aktiva Lancar }}{\text { Utang Lancar }}
$$

Hasil pengukuran rasio apabila rasio lancar rendah dapat dikatakan bahwa perusahaan kurang modal untuk membayar utang. Namun, apabila hasil pengukuran rasio tinggi belum tentu kondisi perusahaan sedang baik. Hal ini dapat saja terjadi karena kas tidak digunakan sebaik mungkin.

\section{Debt to Asset Ratio (DAR)}

Menurut I Made Sudana (2015:95) debt to asset ratio (DAR) yaitu rasio yang digunakan untuk mengukur proporsi dana yang bersumber dari hutang untuk membiayai aktiva perusahaan. Semakin besar rasio ini menunjukkan porsi 
penggunaan hutang dalam membiayai investasi pada aktiva semakin besar, maka risiko keuangan perusahaan akan meningkat atau sebaliknya.

Rumus untuk mencari debt to asset ratio dapat digunakan sebagai berikut:

Debt to Asset Ratio $=\frac{\text { Total Utang }}{\text { Total Aktiva }}$

Hasil pengukuran, apabila rasionya tinggi artinya pendanaan dengan utang semakin banyak, maka semakin sulit bagi perusahaan untuk memperoleh tambahan pinjaman karena dikhawatirkan perusahaan tidak mampu menutupi utang-utangnya dengan aktiva yang dimilikinya. Demikian pula apabila rasionya rendah, semakin kecil perusahaan yang dibiayai dengan utang.

\section{Return On Asset (ROA)}

Menurut Hery (2016:106) return on asset (ROA) merupakan rasio yang menunjukkan seberapa besar kontribusi asset dalam menciptakan laba bersih. Dengan kata lain, rasio ini digunakan untuk mengukur seberapa besar jumlah laba bersih yang akan dihasilkan dari setiap rupiah dana yang tertanam dalam total asset. berikut:

Adapun rumus yang digunakan untuk return on asset (ROA) adalah sebagai

$$
\text { Return On Asset }=\frac{\text { Laba bersih setelah pajak }}{\text { Total Aktiva }} \times 100 \%
$$

Semakin rendah nilai return on asset $(\mathrm{ROA})$, semakin kurang baik keadaan perusahaan. Demikian pula sebaliknya semakin tinggi nilai rasio ini maka akan semakin baik keadaan perusahaan.

\section{METODOLOGI PENELITIAN}

\section{Ruang Lingkup Penelitian}

\section{a) Lokasi Penelitian}

Untuk mengumpulkan data dan informasi dalam penulisan skripsi ini, maka penulis melakukan penelitian dan mengumpulkan data yang berhubungan dengan PT. Indocement Tunggal Prakarsa Tbk yang terdaftar di Bursa Efek Indonesia melalui media internet dengan situs www.idx.co.id dan juga situs www.indocement.co.id.

b) Waktu Penelitian

Waktu yang diperoleh untuk mencari data dan informasi yang dibutuhkan dalam penyusunan skripsi ini, penulis melakukan penelitian selama 7 bulan dimulai dari bulan November 2018 - Juni 2019. Penelitian ini dilaksanakan bertahap diantaranya tahap persiapan, tahap pengumpulan data, tahap pengolahan data, analisis dan kesimpulan.

c) Sifat Penelitian

Dalam penelitian ini penulis melakukan pendekatan dengan studi kasus, sedangkan metode yang penulis gunakan dalam penelitian ini adalah metode deskriptif dan juga menggunakan pendekatan kuantitatif karena data dalam penelitian ini dinyatakan dalam bentuk angka-angka.

\section{Metode Penentuan Populasi dan Sampel}

\section{a) Populasi}

Menurut Sugiyono (2015:61) populasi adalah wilayah generalisasi yang terdiri atas obyek atau subyek yang mempunyai kualitas dan karakteristik tertentu yang ditetapkan oleh peneliti untuk dipelajari dan kemudian ditarik 
kesimpulannya. Populasi yang digunakan dalam penelitian ini adalah neraca dan laporan laba rugi PT. Indocement Tunggal Prakarsa Tbk.

b) Sampel

Menurut Sugiyono (2015:62) sampel adalah bagian dari jumlah dan karakteristik yang dimiliki oleh populasi tersebut. Sampel yang digunakan dalam penelitian ini berupa laporan keuangan PT. Indocement Tunggal Prakarsa Tbk periode 2008-2017.

\section{Metode Pengumpulan Data}

\section{a) Sumber Data}

a. Data Primer

Dalam penelitian ini sumber data primer diambil langsung dari objek penelitiannya yaitu PT. Indocement Tunggal Prakarsa Tbk. Data primer yang digunakan adalah laporan keuangan yang berupa neraca dan laporan laba rugi periode 2008-2017

b. Data Sekunder

Sumber data yang dikumpulkan dalam penyusunan skripsi ini diperoleh dari data sekunder yang diambil dari Bursa Efek Indonesia yaitu PT. Indocement Tunggal Prakarsa Tbk. Adapun data yang digunakan terdiri dari:

1) Laporan neraca PT. Indocement Tunggal Prakarsa Tbk periode 2008-2017.

2) Laporan laba rugi PT. Indocement Tunggal Prakarsa Tbk periode 20082017.

\section{b) Jenis Data}

a. Data Kuantitatif

Data ini berupa angka-angka. Data yang dimaksud adalah laporan keuangan yang berupa neraca dan laba rugi PT. Indocement Tunggal Prakarsa Tbk periode 2008 sampai dengan 2017.

b. Data Kualitatif

Data yang berupa kata, kalimat dan skema gambar. Data ini berupa sejarah PT. Indocement Tunggal Prakarsa Tbk dan struktur organisasi perusahaan.

\section{c) Teknik Pengumpulan Data}

a. Penelitian Kepustakaan

Penelitian yang dilakukan oleh penulis dalam mencari data-data sebagai landasan teori dalam menyusun skripsi, yang dapat diperoleh dengan cara membaca dan mempelajari buku-buku perpustakaan, buku referensi, catatan kuliah, dan bahan pustaka lainnya yang erat hubungannya dengan masalah yang akan dibahas.

b. Penelitian Melalui Internet

Penelitian atau riset ini digunakan dengan cara searching dan download sumber data-data yang berhubungan dengan variabel-variabel penelitian dan yang berkaitan dengan topik permasalahan.

c. Penelitian Dokumentasi

Cara dokumentasi dalam penelitian ini dimaksudkan untuk memperoleh data dengan mempelajari dokumen yang berkaitan dengan seluruh data yang diperlukan dalam penelitian.

\section{Metode Analisa Data}

\section{a) Statistik Deskrptif}


Menurut Imam Ghozali (2016:19) statistik deskriptif adalah statistik yang digunakan untuk memberikan gambaran atau deskripsi suatu data yang dilihat dari nilai minimum, maksimum, rata-rata (mean), standar deviasi, sum, range, kurtosis dan skewness.

\section{b) Uji Asumsi Klasik}

\section{a. Uji Normalitas}

Menurut Imam Ghozali (2016:154) uji normalitas dilakukan untuk menguji apakah dalam model regresi, variabel independen dan variabel dependen atau keduanya mempunyai distribusi normal atau tidak. Pada prinsipnya normalitas data dapat diketahui dengan melihat penyebaran dua (titik) pada sumbu diagonal pada grafik atau histogram dari residualnya. Data normal dan tidak normal dapat diuraikan sebagai berikut (Imam Ghozali, 2016:155):

1) Jika data menyebar di sekitar garis diagonal dan mengikuti arah garis diagonal atau grafik histogramnya, menunjukkan pola terdistribusi normal, maka model regresi memenuhi asumsi normalitas.

2) Jika data menyebar jauh dari garis diagonal dan tidak mengikuti arah garis diagonal atau grafik histogramnya, tidak menunjukkan pola terdistribusi normal, maka model regresi tidak memenuhi asumsi normalitas.

\section{b. Uji Heteroskedastisitas}

Menurut Imam Ghozali (2016:138) uji heteroskedastisitas yaitu untuk menguji apakah dalam model regresi terjadi ketidaksamaan varian dari residual satu pengamatan ke pengamatan yang lain. Jika variance dari residual satu pengamatan ke pengamatan lain tetap, maka disebut homoskedastisitas dan jika berbeda disebut heteroskedastisitas. Cara menditeksi ada atau tidaknya heteroskedastisitas adalah dengan melihat grafik Plot antara nilai prediksi variabel terikat (dependen) yaitu ZPRED dengan residualnya SRESID. Jika ada pola tertentu, seperti titik yang membentuk pola yang teratur maka mengindikasikan telah terjadi heterokedastisitas. Dan jika tidak ada pola yang jelas, serta titik-titik menyebar di atas dan bawah angka 0 (nol) pada sumbu $\mathrm{Y}$, maka tidak heterokedastisitas.

\section{c. Uji Autokorelasi}

Menurut Imam Ghozali (2016:106) uji autokorelasi bertujuan menguji apakah dalam suatu model regresi linier terdapat korelasi antara kesalahan pengganggu pada periode $t$ dengan kesalahan pada periode $t-1$ (sebelumnya). Jika terjadi korelasi, maka dinamakan ada problem autokorelasi. Model regresi yang baik adalah model regresi yang terbebas dari autokorelasi.

Menurut Danang Sunyoto (2016:98) salah satu ukuran dalam menentukan ada tidaknya masalah autokorelasi dengan uji Durbin-Watson (DW) dengan ketentuan sebagai berikut:

1) Bila nilai $D-W$ terletak di bawah -2 atau $D-W<-2$, terjadi autokorelasi positif.

2) Bila nilai $D-W$ terletak di antara -2 sampai +2 atau $-2<D-W<+2$, tidak terjadi autokorelasi.

3) Bila nilai $D-W$ terletak di atas +2 atau $D-W>+2$, terjadi autokorelasi negatif.

\section{d. Uji Multikolinieritas}


Menurut Imam Ghozali (2016:103) pengujian multikolinieritas bertujuan untuk menguji apakah model regresi ditemukan adanya korelasi antara variabel bebas (independen).

Untuk mengetahui apakah ada korelasi diantara variabel-variabel bebas dapat diketahui dengan melihat dari nilai tolerance yang tinggi. Tolerance mengukur variabilitas variabel bebas yang terpilih tidak dapat dijelaskan oleh variabel bebas lainnya. Jadi nilai tolerance yang rendah sama dengan nilai VIF tinggi dan menunjukkan adanya kolineritas yang tinggi. Apabila TOL di bawah 0,1 atau VIF di atas 10, maka terjadi multikolinieritas.

\section{c) Analisis Regresi Linier Berganda}

Menurut Sugiyono (2017:275) analisis regresi linier berganda digunakan untuk meramalkan bagaimana keadaan (naik turunnya) variabel dependen, bila dua atau lebih variabel independen sebagai faktor predictor dimanipulasi (dinaik turunkan nilainya).

Bentuk umum dari persamaan regresi linier berganda menurut Sugiyono (2017:275) adalah sebagai berikut:

$$
\begin{aligned}
& y=a+b_{1} \cdot X_{1}+b_{2} \cdot X_{2}+e \\
& \text { Keterangan: } \\
& Y \quad=\text { ROA } \\
& a \quad=\text { Konstanta } \\
& b_{1,2}=\text { Koefisien regresi } \\
& X_{1}=\text { CR } \\
& X_{2}=\text { DAR } \\
& e \quad=\text { Variabel acak atau kesalahan acak }
\end{aligned}
$$

Analisis regresi linier berganda bertujuan untuk menghitung besarnya pengaruh dua atau lebih variabel bebas terhadap satu variabel terikat dan memprediksi variabel terikat dengan menggunakan dua atau lebih variabel bebas.

\section{d) Uji Korelasi Determinasi}

Menurut Imam Ghozali (2016:98) uji koefisien determinasi $\left(R^{2}\right)$ digunakan untuk mengukur seberapa jauh kemampuan model dalam menerangkan variasi variabel independen.

Jika koefisien determinasi nol berarti variabel independen sama sekali tidak berpengaruh terhadap variabel dependen. Apabila koefisien determinasi semakin mendekati 1 maka semakin besar pengaruh variabel independen terhadap variabel dependen.

\section{e) Uji Hipotesis}

\section{a. Uji Parsial (Uji-t)}

Uji-t digunakan untuk menguji pengaruh masing-masing variabel independen yang digunakan dalam penelitian ini terhadap variabel dependen secara parsial. Untuk menguji pengaruh variabel bebas terhadap variabel terikat digunakan koefisien regresi secara parsial (Uji-t) yaitu dengan membandingkan $t_{\text {hitung }}$ dan $t_{\text {tabel }}$, lalu dibandingkan dengan menggunakan tingkat signifikansi (a) 0,05 dengan uji dua sisi dengan df $=\mathrm{n}-\mathrm{k}(\mathrm{k}=$ jumlah variabel independen). Apabila $t_{\text {hitung }}>t_{\text {tabel }}$ atau nilai signifikansi $<0,05$, maka Ho ditolak dan Ha diterima, artinya terdapat pengaruh yang signifikan antara satu variabel independen terhadap variabel dependen. Dan apabila $t_{\text {hitung }}<$ $t_{\text {tabel }}$ atau nilai signifikansi $>0,05$, maka Ho diterima dan Ha ditolak, artinya 
tidak terdapat pengaruh yang signifikan antara satu variabel independen terhadap variabel dependen.

\section{b. Uji Simultan (Uji-F)}

Uji-F atau uji simultan digunakan untuk mengetahui pengaruh variabel independen secara bersama-sama atau simultan terhadap variabel dependen, apakah pengaruhnya signifikan atau tidak dengan membandingkan $\mathrm{F}_{\text {hitung }}<$ $F_{\text {tabel. }}$ Apabila nilai $F_{\text {hitung }}<F_{\text {tabel }}$ atau nilai signifikansi $>$ dari 0,05 maka Ho diterima dan Ha ditolak, artinya tidak terdapat pengaruh yang signifikan antara satu variabel independen terhadap variabel dependen. Dan apabila nilai $F_{\text {hitung }}$ $>F_{\text {tabel }}$ atau nilai signifikansi < dari 0,05 maka Ho ditolak dan Ha diterima, artinya terdapat pengaruh yang signifikan antara satu variabel independen terhadap variabel dependen.

\section{HASIL DAN PEMBAHASAN}

\section{Hasil dan Pembahasan}

a) Statistik Deskriptif

Tabel 1

\section{Descriptive Statistics}

\begin{tabular}{|l|l|l|l|l|l|}
\hline & $\mathrm{N}$ & Min & Max & Mean & Std. Deviation \\
\hline CR & 10 & 178,54 & 698,38 & 475,4980 & 157,23286 \\
DAR & 10 & 13,31 & 24,50 & 15,6920 & 3,56166 \\
ROA & 10 & 6,44 & 21,02 & 17,0090 & 4,60624 \\
Valid N (listwise) & 10 & & & & \\
\hline
\end{tabular}

Sumber: Hasil Output SPSS 20

Berdasarkan hasil perhitungan tabel 1 di atas nilai $\mathrm{N}$ menunjukkan banyaknya data yang digunakan dalam penelitian, yaitu sebanyak 10 data, yang merupakan jumlah sample selama periode penelitian 2008 sampai dengan 2017 . Variabel Current Ratio memiliki nilai minimum sebesar 178,54 dan nilai maksimum sebesar 693,38 dan mempunyai rata-rata (mean) sebesar 475,4980 dengan nilai standar deviasinya sebesar 157,23286. Sedangkan variabel Debt to Asset Ratio memiliki nilai minimum sebesar 13,31 dan nilai maksimum sebesar 24,50 dan mempunyai nilai rata-rata (mean) sebesar 15,6920 dengan nilai standar deviasinya sebesar 3,56166. Dan variabel Return On Asset memiliki nilai minimum sebesar 6,44 dan nilai maksimum sebesar 21,02 dan mempunyai nilai rata-rata (mean) sebesar 17,0090 dengan nilai standar deviasinya sebesar 4,60624.

b) Uji Asumsi Klasik

\section{a. Uji Normalitas}

Hasil pengujian normalitas data dengan grafik Normal Probability Plot: Sumber: Hasil Output SPSS 20

\section{Gambar 1}

Normal Probability Plot 


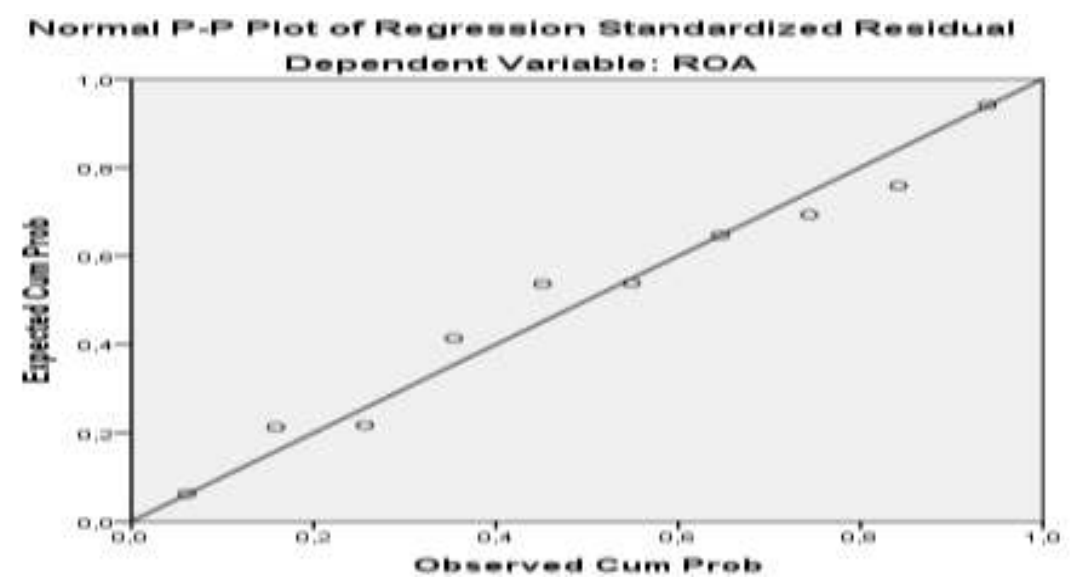

Dari gambar 1 di atas dapat dilihat bahwa data grafik normal probability plot tersebar disekitar garis diagonal dan mengikuti arah garis lurus (tidak tersebar jauh dari garis lurus), maka dapat dikatakan bahwa model regresi yang digunakan telah memenuhi asumsi normalitas atau data berdistribusi normal. Analisis lebih lanjut dengan melihat statistik kolmogorov-smirnov test dapat dilihat pada tabel di bawah ini:

Tabel 2

Hasil Uji Kolmogrov-Smirnov

One-Sample Kolmogorov-Smirnov Test

\begin{tabular}{|ll|l|}
\hline & & Unstandardized Residual \\
\hline $\mathrm{N}$ & & 10 \\
Normal Parameters & Mean & $0 \mathrm{E}-7$ \\
& Std. Deviation & 2,96865567 \\
& Absolute &, 142 \\
Most Extreme Differences & Positive &, 113 \\
& Negative &,- 142 \\
Kolmogorov-Smirnov $Z$ & &, 449 \\
Asymp. Sig. (2-tailed) & &, 988 \\
\hline
\end{tabular}

a. Test distribution is Normal.

b. Calculated from data.

Sumber: Hasil Output SPSS 20

Berdasarkan tabel 2 dapat dilihat hasil uji normalitas menggunakan Kolmogorov-Smirnov, bahwa nilai signifikan adalah sebesar 0,988 > 0,05 yang menunjukkan bahwa residual mempunyai berdistribusi yang normal. Dengan demikian, asumsi atau persyaratan normalitas dalam model regresi sudah terpenuhi.

\section{b. Uji Multikolinearitas}

Uji multikolinearitas dilakukan dengan melihat nilai tolerance dan variance inflation factor (VIF) apabila tolerance value lebih tinggi daripada 0,10 atau VIF lebih kecil daripada 10 maka dapat disimpulkan tidak terjadi multikolinearitas. 
Tabel 3

\section{H}

Coefficients $^{\mathrm{a}}$

\begin{tabular}{|l|l|l|}
\hline \multirow{2}{*}{ Model } & \multicolumn{2}{|l|}{ Collinearity Statistics } \\
\cline { 2 - 3 } & Tolerance & VIF \\
\hline (Constant) & & \\
1 CR &, 308 & 3,250 \\
DAR &, 308 & 3,250 \\
\hline
\end{tabular}

a. Dependent Variable: ROA

Sumber: Hasil Output SPSS 20

\section{Multikolinearitas}

Berdasarkan dari tabel diatas dapat dilihat nilai tolerance value Current Ratio dan Debt to Asset Ratio lebih tinggi daripada 0,10 yaitu sebesar 0,308 serta nilai VIF Current Ratio dan Debt to Asset Ratio lebih kecil daripada 10 yaitu sebesar 3,250. Maka dapat disimpulkan tidak terjadi multikolinearitas.

\section{c. Uji Heteroskedastisitas}

Uji heterokedastisitas ini dapat dilihat pada gambar yang terdapat di bawah

Beatterpiot ini:

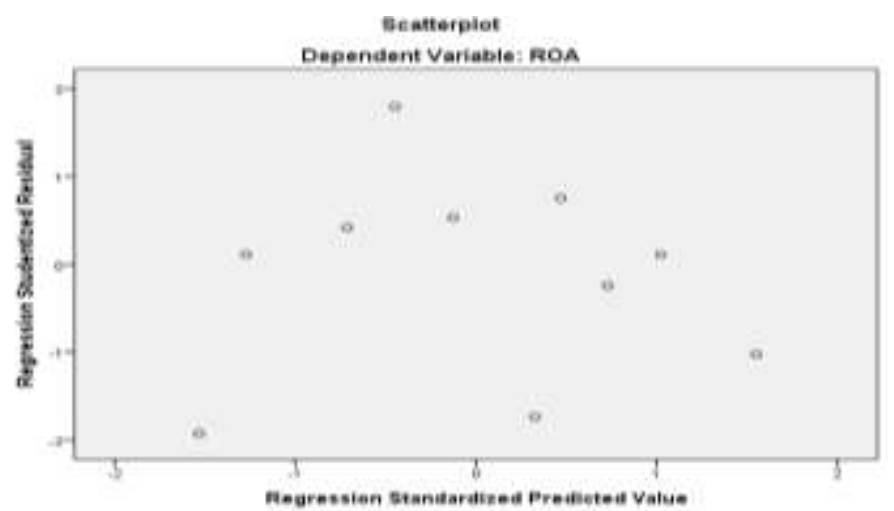

Sumber: Hasil Output SPSS 20

\section{Gambar 2 \\ Scatterplot}

Berdasarkan grafik di atas terlihat bahwa titik-titik pada grafik relatif menyebar secara merata dan tidak memberikan pola tertentu. Ini berarti tidak terjadi masalah heterokedastisitas.

\section{d. Uji Autokorelasi}

Jika nilai DW terletak di antara -2 sampai +2 berarti tidak ada autokorelasi. 
Tabel 4

Hasil Uji Durbin-Watson

Model Summary

\begin{tabular}{|l|l|l|l|l|l|}
\hline Model & $R$ & $R$ Square & $\begin{array}{l}\text { Adjusted } \\
\text { Square }\end{array}$ & $\begin{array}{l}\text { Std. Error of } \\
\text { the Estimate }\end{array}$ & Durbin-Watson \\
\hline 1 &, $765^{\mathrm{a}}$ &, 585 &, 466 & 3,36614 & 1,807 \\
\hline
\end{tabular}

a. Predictors: (Constant), DAR, CR

b. Dependent Variable: ROA

Sumber : Hasil Output SPSS 20

Berdasarkan tabel 4 di atas, uji autokorelasi yang menggunakan DurbinWatson menunjukkan nilai sebesar 1,807 oleh karena angka DW berada antara -2 sampai +2 hal ini berarti bahwa tidak ada autokorelasi.

\section{c) Uji Regresi Linier Berganda} 20:

Berikut ini tabel uji regresi linier berganda dari hasil olahan data spss versi

Tabel 5

Coefficients $^{\mathrm{a}}$

\section{Hasil Uji Regresi Linier Berganda}

\begin{tabular}{|ll|l|l|}
\hline \multirow{2}{*}{ Model } & \multicolumn{2}{|c|}{ Unstandardized Coefficients } \\
\cline { 3 - 4 } & (Constant) & $-25,588$ & Std. Error \\
\hline \multirow{2}{*}{1} & CR &, 040 & 14,445 \\
& DAR & 1,491 &, 013 \\
\hline
\end{tabular}

a. Dependent Variable: ROA

Sumber: Hasil Output SPSS 20

Berdasarkan hasil analisis regresi linier berganda pada tabet 5 di atas, maka diperoleh persamaan regresi linier berganda sebagai berikut:

$Y=-25,588+0,040 X_{1}+1,491 X_{2}+e$

Interprestasi dari persamaan tersebut adalah:

1) Dari persamaan regresi linier berganda di atas, diketahui mempunyai konstanta bertanda negatif sebesar -25,588. Sehingga besaran konstanta menunjukkan bahwa jika variabel-variabel independen (CR dan DAR) diasumsikan 0, maka variabel dependen yaitu ROA sebesar -25,588.

2) Variabel CR mempunyai koefisien yang bertanda positif sebesar 0,040 . Hal ini berarti bahwa jika CR mengalami kenaikan satu persen (1\%) maka ROA akan mengalami peningkatan sebesar 0,040.

3) Variabel DAR mempunyai koefisien yang bertanda positif sebesar 1,491. Artinya jika DAR mengalami kenaikan satu persen (1\%) maka ROA akan mengalami peningkatan sebesar 1,491.

\section{d) Uji Koefisien Determinasi}

Berikut adalah hasil olah data nilai koefisien determinasi dengan menggunakan program SPSS versi 20 , dapat dilihat pada tabel di bawah ini: 


\section{Tabel 6 \\ Hasil Uji Koefisien Determinasi}

Model Summary ${ }^{\text {b }}$

\begin{tabular}{|l|l|l|l|l|}
\hline Model & R & R Square & Adjusted R Square & $\begin{array}{l}\text { Std. Error of the } \\
\text { Estimate }\end{array}$ \\
\hline 1 &, $765^{\mathrm{a}}$ &, 585 &, 466 & 3,36614 \\
\hline
\end{tabular}

a. Predictors: (Constant), DAR, CR

b. Dependent Variable: ROA

Sumber: Hasil Output SPSS 20

Hasil dari analisis yang diperoleh di atas dapat diketahui nilai $\mathrm{R}^{2}$ sebesar 0,585. Artinya pengaruh variabel independen Current Ratio (CR) dan Debt to Asset Ratio (DAR) sebesar $58,5 \%$, sedangkan sisanya sebesar $41,5 \%$ dipengaruhi oleh variabel lainnya yang tidak dimasukan dalam penelitian ini.

\section{e) Uji Hipotesis}

\section{a. Uji Parsial (Uji t)}

Pengujian hipotesis dengan $\alpha=5 \%=0,05$, sedangkan derajat bebas pengujian adalah $n-k=10-2=8$. Dalam hal ini $t_{\text {tabel }}$ adalah $(0,05 ; 8)$. Maka $t_{\text {tabel }}$ sebesar 2,306. Berikut adalah hasil output uji t menggunakan SPSS versi 20 :

\section{Tabel 7}

\section{Hasil Uji t (Parsial)}

\begin{tabular}{|ll|l|l|}
\hline Model & & $\mathrm{t}$ & Sig. \\
\hline \multirow{3}{*}{1} & (Constant) & $-1,771$ &, 120 \\
& CR & 3,139 &, 016 \\
& DAR & 2,626 &, 034 \\
\hline
\end{tabular}

a. Dependent Variable: ROA

Sumber: Hasil Output SPSS 20

1) Berdasarkan tabel di atas dapat dilihat bahwa variabel $C R$ ada pengaruh signifikan terhadap ROA dilihat dari nilai signifikansi sebesar 0,016 lebih kecil dari batas nilai signifikansi sebesar 0,05. Sedangkan dengan membandingkan hasil perhitungan nilai $t_{\text {hitung }}$ dengan $t_{\text {tabel }}$ dapat dilihat bahwa nilai $t_{\text {hitung }}$ lebih besar daripada $t_{\text {tabel }}$ atau sebesar 3,139 $>2,306$ artinya Ho ditolak dan Ha diterima, maka dapat disimpulkan bahwa CR ada pengaruh signifikan terhadap ROA.

2) Berdasarkan tabel di atas dapat dilihat bahwa variabel DAR ada pengaruh signifikan terhadap ROA dilihat dari nilai signifikansi sebesar 0,034 lebih besar dari batas nilai signifikansi sebesar 0,05. Sedangkan dengan membandingkan hasil perhitungan nilai $t_{\text {hitung }}$ dengan $t_{\text {tabel }}$ dapat dilihat bahwa nilai $t_{\text {hitung }}$ lebih besar daripada $t_{\text {tabel }}$ atau sebesar 2,626 $<2,306$ artinya Ho ditolak dan Ha diterima, maka dapat disimpulkan bahwa DAR ada pengaruh signifikan terhadap ROA.

\section{b. Uji F (Simultan)}

$F_{\text {tabel }}$ dapat dicari pada tabel uji $F$ dengan signifikansi $5 \%(0,05)$ dengan $\mathrm{df} 1=\mathrm{k}-1$ yaitu df $1=3-1=2$ dan df $2=\mathrm{n}-\mathrm{k}$ yaitu df2 $=10-3=7, \mathrm{k}$ adalah jumlah variabel independen ditambah variabel dependen dan $\mathrm{n}$ adalah 
banyaknya data yang digunakan. Maka nilai $F_{\text {tabel }}$ yang didapat dengan melihat di tabel distribusi $F$ yaitu sebesar 4,74.

\section{Tabel 8}

Hasil Uji F (Simultan)

ANOVA $^{\mathrm{a}}$

\begin{tabular}{|ll|l|l|}
\hline Model & F & Sig. \\
\hline $1 \begin{array}{l}\text { Regression } \\
\text { Residual } \\
\text { Total }\end{array}$ & 4,926 &, $046^{\mathrm{b}}$ \\
\hline
\end{tabular}

a. Dependent Variable: ROA

b. Predictors: (Constant), DAR, CR

umber: Hasil Output SPSS 20

Berdasarkan tabel di atas, dapat dilihat bahwa variabel-variabel independen berpengaruh signifikan terhadap variabel dependen dengan nilai signifikansi sebesar 0,046 lebih kecil dari batas nilai signifikansi sebesar 0,05. Sedangkan dengan membandingkan hasil perhitungan nilai diketahui nilai $\mathrm{F}_{\text {hitung }}$ lebih besar dari $F_{\text {tabel }}$ yaitu 4,926 < 4,74 yang artinya terdapat pengaruh yang signifikan antara variabel independen terhadap variabel dependennya sehingga Ho ditolak dan Ha diterima. Dengan demikian dapat ditarik kesimpulan bahwa terdapat pengaruh signifikan dari Current Ratio (CR) dan Debt to Asset Ratio (DAR) terhadap Return On Asset (ROA) secara bersama-sama (simultan).

\section{E. SIMPULAN}

\section{Kesimpulan}

Penelitian ini dilakukan untuk menguji Current Ratio dan Debt to Asset Ratio terhadap Return On Asset pada PT. Indocement Tunggal Prakarsa, Tbk. Berdasarkan hasil penelitian yang dilakukan maka dapat disimpulkan sebagai berikut:

1) Pengaruh Current Ratio terhadap Return On Asset pada PT. Indocement Tunggal Prakarsa, Tbk. Dari hasil analisa uji t menunjukkan $t_{\text {hitung }}$ sebesar 3,139 dengan nilai signifikansi sebesar 0,016 dan $t_{\text {tabel }} 2,306$. Maka ( $t_{\text {hitung }}>t_{\text {tabel }}$ ) dikarenakan $3,139>$. 2,306 dan nilai signifikansi $0,016<0,05$, sehingga Ha diterima dan Ho ditolak. Maka dapat disimpulkan bahwa Current Ratio secara parsial berpengaruh signifikan terhadap Return On Asset pada PT. Indocement Tunggal Prakarsa, Tbk periode 2008-2017.

2) Pengaruh Debt to Asset Ratio terhadap Return On Asset pada PT. Indocement Tunggal Prakarsa, Tbk. Dari hasil analisa uji t menunjukkan $t_{\text {hitung }}$ sebesar 2,626 dengan nilai signifikansi sebesar 0,034 dan $t_{\text {tabel }} 2,306$. Maka ( $t_{\text {hitung }}>t_{\text {tabel }}$ ) dikarenakan 2,626 > 2,306 dan nilai signifikansi 0,034<0,05, sehingga $\mathrm{Ha}$ diterima dan Ho ditolak. Maka dapat disimpulkan bahwa Debt to Asset Ratio secara parsial berpengaruh signifikan terhadap Return On Asset pada PT. Indocement Tunggal Prakarsa, Tbk periode 2008-2017.

3) Pengaruh Current Ratio dan Debt to Asset Ratio terhadap Return On Asset pada PT. Indocement Tunggal Prakarsa, Tbk. Dari hasil analisa uji $F$ menunjukkan $F_{\text {hitung }}$ sebesar 4,926 dengan nilai signifikansi sebesar 0,046 dan $F_{\text {tabel }} 4,74$. Maka $\left(F_{\text {hitung }}\right.$ $>F_{\text {tabel }}$ ) dikarenakan 4,926 > 4,74 dan nilai signifikansi 0,046 <0,05, sehingga $\mathrm{Ha}$ diterima dan Ho ditolak. Maka dapat disimpulkan bahwa secara simultan Current Ratio dan Debt to Asset Ratio berpengaruh signifikan terhadap Return On Asset pada PT. Indocement Tunggal Prakarsa, Tbk periode 2008-2017. 


\section{Saran}

Berdasarkan hasil analisa dan kesimpulan penelitian di atas, ada beberapa hal yang dapat disarankan oleh peneliti, yaitu:

1. Bagi para manajer perusahaan, karena hasil penelitian ini menunjukkan bahwa Current Ratio dan Debt To Asset Ratio berpengaruh signifikan. Maka perusahaan harus memperhatikan rasio-rasio keuangan lainnya seperti Cash Ratio, Total Assets Turnover, dan lainnya yang juga merupakan faktor-faktor yang dapat mempengaruhi besar kecilnya Return On Asset sebuah perusahaan.

2. Bagi para investor dan calon investor agar dapat menilai kinerja perusahaan yang menjadi sasaran investasi, tidak hanya memperhatikan tingkat Return On Asset perusahaan tetapi juga sebaiknya memperhatikan hal-hal yang dapat mempengaruhinya sehingga pengambilan keputusan investasi tepat.

3. Bagi peneliti selanjutnya, diharapkan dapat mengembangkan penelitian ini dengan menambahkan variabel independent lainnya yang dapat berpengaruh terhadap Return On Asset perusahaan. 


\section{DAFTAR PUSTAKA}

Fahmi, Irham. 2016. Pengantar Manajemen Keuangan. Bandung: Alfabeta.

Ghozali, Imam. 2016. Aplikasi Analisis Multivariate Dengan Program SPSS. Semarang: Universitas Diponegoro.

Handoko, T. Hani. 2015. Manajemen, Edisi Kedua. Yogyakarta: Penerbit BPFE.

Harahap, Sofyan Syafri. 2015. Analisis Kritis atas Laporan Keuangan. Jakarta: PT.Rajawali Grafindo Persada.

Hasibuan, Malayu S.P. 2016. Manajemen Sumber Daya Manusia, Edisi Revisi. Jakarta: PT. Bumi Aksara.

Hery. 2016. Analisis Laporan Keuangan - Integrated And Comprehensive Edition. Jakarta: PT. Grasindo.

Ikatan Akuntansi Indonesia (IAI). 2017. Standar Akuntansi Keuangan. Jakarta: Salemba Empat.

Kadim, A., \& Sunardi, N. (2019, May). Eviews Analysis; Determinan Tourism, Restaurant and Hotel Company's Soundness and Performance. In Proceeding Interuniversity Forum for Strengthening Academic Competency (Vol. 1, No. 1, pp. 332-340).

Kasmir. 2016. Analisis Laporan Keuangan, Edisi Pertama, Cetakan Kesembilan. Jakarta: PT Raja Grafindo Persada.

Lutfi, A. M., \& Sunardi, N. (2019). Pengaruh Current Ratio (Cr), Return On Equity (Roe), Dan Sales Growth Terhadap Harga Saham Yang Berdampak Pada Kinerja Keuangan Perusahaan (Pada Perusahaan Manufaktur Sektor Makanan Dan Minuman Yang Terdaftar Di Bursa Efek Indonesia). Jurnal SEKURITAS (Saham, Ekonomi, Keuangan dan Investasi), 2(3), 83-100.

Mamduh M. Hanafi dan Abdul Halim. 2016. Analisis Laporan Keuangan. Yogyakarta: AMP-YKPN.

Nardi Sunardi, E. A., Kadim, A., Tumanggor, M., \& Oktrima, B. (2018). Effects Of The Bank Soundness With The Rbbr Approach (Risk Base Bank Rating) Of Cost Efficiency And Its Implications On Sharia Bank Performance In Indonesia For The Period Of 2012-2016. International Journal of Economic Research, 15(1).

Sudana, I Made Sudana. 2015. Teori dan Praktik Manajemen Keuangan Perusahaan, Edisi 2. Jakarta: Erlangga.

Sugiyono. 2015. Metode Penelitian Kuantitatif, Kualitatif, dan R\&D. Bandung: Alfabeta.

Sugiyono. 2017. Statistika Untuk Penelitian. Bandung: Alfabeta.

Sunardi, N. (2017). Determinan Kebijakan Utang Serta Implikasinya terhadap Kinerja Perusahaan (Perusahaan yang tergabung dalam indeks LQ. 45 yang terdaftar di Bursa Efek Indonesia Tahun 2011-2015). Jurnal Sekuritas, 1(1).

Sunardi, N. (2018). Analisis Du Pont System Dengan Time Series Approach (Tsa) Dan Cross Sectional Approach (Csa) Dalam Penilaian Kinerja Keuangan Perusahaan (Studi Pada Industri Konstruksi (BUMN) di Indonesia Yang Listing di BEI Tahun 2013-2017). Jurnal SEKURITAS (Saham, Ekonomi, Keuangan dan Investasi), 1(4).

Sunardi, N. (2019). Determinan Intelectual Capital dengan Pendekatan iB-VAIC ${ }^{\text {TM }}$ Terhadap Efisiensi Biaya Implikasinya Pada Profitabilitas Perbankan Syariah di Indonesia. JIMF (Jurnal IImiah Manajemen Forkamma), 1(1).

Sunardi, N., \& Sasmita, A. S. (2019). Pengaruh Likuiditas, Leverage Dan Growth Terhadap Kinerja Industri Makanan Dan Minuman Yang Tercatat Di Indonesia Stock Exchange Selama Periode Tahun 2011-2015. Jurnal SEKURITAS (Saham, Ekonomi, Keuangan dan Investasi), 2(2), 81-97.

Sunardi, N., Hamid, A. A., Lativa, A. K., \& Tulus, N. (2018). Determinant Of Cost Efficiency And It's Implications For Companies Performance Incorporated In The Lq. 45 Index Listing In Idx For The Period of 2011-2016. International Journal of Applied Business and Economic Research, 16(1). 